\title{
COMMENTARY
}

\section{Totem and Taboo: Fluids in sepsis}

Andrew K Hilton' and Rinaldo Bellomo*2

\begin{abstract}
The need for early, rapid, and substantial fluid resuscitation in septic patients has long been an article of faith in the intensive care community, a tribal totem that is taboo to question. The results of a recent multicenter trial in septic children in Africa, published in The New England Journal of Medicine, powerfully challenge the fluid paradigm. The salient aspects of the trial need to be understood and reflected upon. In this commentary, we discuss the background to and findings of the trial and explain why they will likely trigger a re-evaluation of our thinking about fluids in sepsis, a re-evaluation that is already happening in the treatment of acute respiratory distress syndrome and acute kidney injury and in postoperative care.
\end{abstract}

Current guidelines for the acute management of severe sepsis in pediatric and adult patients place prime importance on early, rapid, and substantial infusion of intravenous fluids $[1,2]$. The immediate aim is to correct a possible fluid responsive hypodynamic circulation [1-3]. Beyond this, the common assumption is that expansion of effective circulating volume will attenuate hypotension, ameliorate the perceived impaired peripheral and endorgan perfusion, and correct abnormalities of base deficit and lactate. Curiously, this assumption is held despite the well-known fact that cardiac output is often elevated in septic adults [4-6] and children [7,8] even though myocardial performance may be impaired [9]. Furthermore, in children, sepsis-induced myocardial dysfunction [10] may increase the chance of fluid unresponsiveness. In fact, in both adults and children, no controlled data exist that increases in cardiac output due to volume expansion are beneficial or even reliably achieved [11]. Moreover, no human data show that substantial $(>20 \mathrm{~mL} / \mathrm{kg}$ ) fluid resuscitation reliably improves blood

${ }^{*}$ Correspondence: rinaldo.bellomo@austin.org.au

${ }^{2}$ Australian and New Zealand Intensive Care Research Centre, Commercial Road,

Melbourne, Victoria 3181, Australia

Full list of author information is available at the end of the article pressure or end-organ perfusion (an elusive outcome given that organ blood flow cannot be accurately measured in septic humans). Finally, experimental data show that organ perfusion is supranormal in hyperdynamic sepsis [12] and that fluid resuscitation may increase mortality [13].

The publication of FEAST (Fluid Expansion As Supportive Therapy in critically ill African children) [14] challenges the widely held totemic beliefs in the protective power of fluids in severe sepsis. It also breaks the taboo that has made any challenge to fluid therapy in the sepsis paradigm an act of unspeakable tribal treason. Yet FEAST is the first large and randomized study of the relationship between volume and composition of intravenous fluids and clinical outcome in acute severe sepsis. The results challenge the status quo.

FEAST enrolled Sub-Saharan African children with a severe febrile illness (prostration, coma, or respiratory distress) and clinical evidence of impaired peripheral perfusion. Overall, 3,141 patients without severe hypotension were randomly assigned to one of three groups $(\mathrm{n}=1,047$ in each group): 20 to $40 \mathrm{~mL} / \mathrm{kg}$ boluses of $5 \%$ albumin or $0.9 \%$ saline or no bolus fluids (FEAST A). All three groups were given intravenous maintenance fluids ( 2.5 to $4 \mathrm{~mL} / \mathrm{kg}$ per hour), blood transfusion if the hemoglobin was less than $5 \mathrm{~g} / \mathrm{dL}(20 \mathrm{~mL} / \mathrm{kg}$ over the course of 4 hours), and appropriate antibiotics, antimalarials, anticonvulsants, antipyretics, and blood sugar management as indicated. The primary endpoint was mortality at 48 hours.

By 8 hours, the median cumulative volumes (including transfused blood) received were 40,40 , and $10.1 \mathrm{~mL} / \mathrm{kg}$ for the albumin bolus, saline bolus, and control arms, respectively. Most of this difference occurred over the course of the first two hours. Overall 48-hour mortality was $9.5 \%$ and most deaths occurred within 24 hours, but a striking difference was found between the control group and the bolus fluid groups: 48-hour mortality rates were $7.3 \%, 10.6 \%$, and $10.5 \%$ for the control, albumin bolus, and $0.9 \%$ bolus groups, respectively. The 48 -hour mortality of the combined bolus group had increased by $45 \%(P=0.003)$.

Not only are the overall results clinically and statistically significant but a dose effect is evident. After 2,535 subjects had been enrolled, the initial sample size was 
increased because of a lower-than-expected mortality rate. As part of this amendment, the bolus volume was increased from 20 to $40 \mathrm{~mL} / \mathrm{kg}$. However, enrollment was ceased after a further 606 subjects (total of 3,141 subjects) because of safety concerns about excess harm to the bolus groups. The postamendment mortality of the bolus groups (12.1\%) was higher than that in preamendment group (10.2\%), and there was no change between preamendment and postamendment outcomes for the control patients. The postamendment effect suggests that mortality increased because the dose of bolus fluids increased.

What conclusions can intensivists working in modern ICUs draw from FEAST? First, the pediatric nature of the cohort (median age of 2 years) should invite caution in extrapolating these findings to an adult population. Second, $59 \%$ of the patients had malaria, although the adverse effect of bolus fluids was significant in both malarial and nonmalarial subgroups. Third, there was insufficient information about the causes of death, details of which would allow a more insightful analysis of the mechanisms linking bolus fluid administration to mortality. Finally, and very importantly, the FEAST 'package' did not include ICU admission or the use of mechanical ventilation, inotropic or vasopressor drugs, or continuous renal replacement therapy (CRRT).

There is no evidence that, when ICU supports are available, volume expansion of the order of $40 \mathrm{~mL} / \mathrm{kg}$ (the largest volume in FEAST) increases 48-hour mortality. Yet there is a growing body of evidence that a positive fluid balance might contribute to significant morbidity in patients with sepsis [15], acute respiratory distress syndrome [16], acute kidney injury [17], or major surgery [18]. It is, therefore, biologically and physiologically plausible that excessive fluid administration is harmful but that, owing to the masking effects of other supportive interventions, such harm is not immediately recognized in a Western context. Thus, mechanical ventilation, inotropes, vasopressors, and CRRT prevent increases in early mortality but at the price of delayed and unrecognized increases in the risk of a more prolonged subsequent organ failure [16,17]. Relevant to such reflections, the failure of short-term physiological gain to translate into medium- or long-term clinical benefit has a long and sad history in critical care medicine $[16,19,20]$.

FEAST will undoubtedly cause robust debate and anxiety as the totemic status of fluids in sepsis becomes undermined. This is a result that Sigmund Freud, the author of Totem and Taboo [21], would have anticipated. His and our answer is the need to confront and more fully investigate. To question the role of fluids in severe sepsis can no longer be considered taboo.

\section{Abbreviations}

CRRT, continuous renal replacement therapy; FEAST, Fluid Expansion As Supportive Therapy in critically ill African children; ICU, intensive care unit.
Competing interests

The authors declare that they have no competing interests.

\section{Author details}

'Department of Intensive Care, Alfred Hospital, Commercial Road, Melbourne, Australia, Victoria 3181, Australia. ${ }^{2}$ Australian and New Zealand Intensive Care Research Centre, Commercial Road, Melbourne, Victoria 3181, Australia.

\section{Published: 10 June 2011}

\section{References}

1. Dellinger RP, Levy MM, Carlet JM, Bion J, Parker MM, Jaeschke R, Reinhart K, Angus DC, Brun-Buisson C, Beale R, Calandra T, Dhainaut JF, Gerlach H, Harvey M, Marini JJ, Marshall J, Ranieri M, Ramsay G, Sevransky J, Thompson BT, Townsend S, Vender JS, Zimmerman JL, Vincent JL: Surviving Sepsis Campaign: international guidelines for management of severe sepsis and septic shock: 2008. Intensive Care Med 2008, 34:17-60.

2. Brierley J, Carcillo JA, Choong K, Cornell T, Decaen A, Deymann A, Doctor A, Davis A, Duff J, Dugas MA, Duncan A, Evans B, Feldman J, Felmet K, Fisher G, Frankel L, Jeffries H, Greenwald B, Gutierrez J, Hall M, Han YY, Hanson J, Hazelzet J, Hernan L, Kiff J, Kissoon N, Kon A, Irazuzta J, Lin J, Lorts A, et al.: Clinical practice parameters for hemodynamic support of pediatric and neonatal septic shock: 2007 update from the American College of Critical Care Medicine. Crit Care Med 2009, 37:666-688.

3. Kissoon N, Orr RA, Carcillo JA: Updated American College of Critical Care Medicine--pediatric advanced life support guidelines for management of pediatric and neonatal septic shock: relevance to the emergency care clinician. Pediatr Emerg Care 2010, 26:867-869.

4. Spöhr F, Hettrich P, Bauer H, Haas U, Martin E, Böttiger BW: Comparison of two methods for enhanced continuous circulatory monitoring in patients with septic shock. Intensive Care Med 2007, 33:1805-1810.

5. Sun Q, Rogiers P, Pauwels D, Vincent JL: Comparison of continuous thermodilution and bolus cardiac output measurements in septic shock. Intensive Care Med 2002, 28:1276-1280.

6. Michard F, Alaya S, Zarka V, Bahloul M, Richard C, Teboul JL: Global enddiastolic volume as an indicator of cardiac preload in patients with septic shock. Chest 2003, 124:1900-1908.

7. Schiffmann $H$, Erdlenbruch B, Singer D, Singer S, Herting E, Hoeft A, Buhre W: Assessment of cardiac output, intravascular volume status, and extravascular lung water by transpulmonary indicator dilution in critically ill neonates and infants. J Cardiothorac Vasc Anesth 2002, 16:592-597.

8. de Waal K, Evans $\mathrm{N}$ : Hemodynamics in preterm infants with late-onset sepsis. J Pediatr 2010, 156:918-922

9. Werdan K, Oelke A, Hettwer S, Nuding S, Bubel S, Hoke R, Ruß M, Lautenschläger C, Mueller-Werdan U, Ebelt H: Septic cardiomyopathy: hemodynamic quantification, occurrence, and prognostic implications. Clin Res Cardio/ 2011 Feb 11. [Epub ahead of print].

10. Carcillo JA, Fields Al: Clinical practice parameters for hemodynamic support of pediatric and neonatal patients in septic shock. Crit Care Med 2002, 30:1365-1378.

11. Jardin F, Fourme T, Page B, Loubières Y, Vieillard-Baron A, Beauchet A Bourdarias JP: Persistent preload defect in severe sepsis despite fluid loading: a longitudinal echocardiographic study in patients with septic shock. Chest 1999, 116:1354-1359.

12. Di Giantomasso D, May C, Bellomo R: Vital organ blood flow in hyperdynamic sepsis. Chest 2003, 124:1053-1059.

13. Brandt S, Regueira T, Bracht H, Porta F, Djafarzadeh S, Takala J, Gorrasi J Borotto E, Krejci V, Hiltebrand LB, Bruegger LE, Beldi G, Wilkens L, Lepper PM, Kessler U, Jakob SM: Effect of fluid resuscitation on mortality and organ function in experimental sepsis models. Crit Care 2009, 13:R186.

14. Maitland K, Kiguli S, Opoka RO, Engoru C, Olupot-Olupot P, Akech SO, Nyeko R, Mtove G, Reyburn H, Lang T, Brent B, Evans JA, Tibenderana JK, Crawley J, Russell EC, Levin M, Babiker AG, Gibb DM; the FEAST Trial Group: Mortality after fluid bolus in African children with severe infection. N Engl J Med 2011 May 26. [Epub ahead of print].

15. Durairaj L, Schmidt GA: Fluid therapy in resuscitated sepsis: less is more. Chest 2008, 133:252-263.

16. National Heart, Lung, and Blood Institute Acute Respiratory Distress Syndrome (ARDS) Clinical Trials Network, Wiedemann HP, Wheeler AP, Bernard GR, Thompson BT, Hayden D, deBoisblanc B, Connors AF Jr., Hite RD, Harabin $A L$ : Comparison of two fluid-management strategies in acute lung injury. 
N Engl J Med 2006, 354:2564-2575

17. Prowle J, Echeveri JE, Ligabo EV, Ronco C, Bellomo R: Fluid balance and acute kidney injury. Net Rev Nephrol 2010, 6:107-115.

18. Brandstrup B, Tønnesen H, Beier-Holgersen R, Hjortsø E, Ørding H, LindorffLarsen K, Rasmussen MS, Lanng C, Wallin L, Iversen LH, Gramkow CS, Okholm M, Blemmer T, Svendsen PE, Rottensten HH, Thage B, Riis J, Jeppesen IS, Teilum D, Christensen AM, Graungaard B, Pott F; Danish Study Group on Perioperative Fluid Therapy: Effects of intravenous fluid restriction on postoperative complications: comparison of two peri-operative fluid regimens: a randomized assessor-blinded multicenter trial. Ann Surg 2003, 238:641-648.

19. NICE-SUGAR Study Investigators, Finfer S, Chittock DR, Su SY, Blair D, Foster D, Dhingra V, Bellomo R, Cook D, Dodek P, Henderson WR, Hébert PC, Heritier S,
Heyland DK, McArthur C, McDonald E, Mitchell I, Myburgh JA, Norton R, Potter J, Robinson BG, Ronco JJ: Intensive versus conventional glucose control in critically ill patients. N Engl J Med 2009, 360:1283-1297.

20. Cooper DJ, Rosenfeld JV, Murray L: Decompressive craniectomy in diffuse traumatic brain injury. N Eng/ J Med 2011, 364:1493-1502.

21. Freud S: Totem and Taboo: Resemblances Between the Psychic Lives of Savages and Neurotics. Translated by Brill AA. Bangkok: ThaiSunset Publications; 2011.

doi:10.1186/cc10247

Cite this article as: Hilton AK, Bellomo R: Totem and Taboo: Fluids in sepsis. Critical Care 2011, 15:164 